\title{
Temporal variation in shell and soft tissue growth of the mussel Geukensia demissa*
}

\author{
Francisco J. Borrero, Thomas J. Hilbish \\ Department of Biology and Belle W. Baruch Institute, University of South Carolina, Columbia, South Carolina 29208, USA
}

\begin{abstract}
Previous studies on bivalve molluscs have not provided a consensus on whether shell and soft tissue growth occur simultaneously. This study provides separate estimates of shell and soft tissue growth of a mid-intertidal population of the ribbed mussel Geukensia demissa from South Carolina, USA. Growth of these 2 parameters did not occur coincidentally at all times. The rate of growth in soft tissue was variable between January and May, but consistently high between May and October Shell growth increased steadily through the year to a maximum between June and July. The rate of growth in shell length decreased after spawning in August, but tissue growth continued at a high rate. Declines in tissue weight were observed at 3 separate times, one of which occurred during the period of fastest increase in shell length. Age-length curves and recorded growth in shell length suggest that annual growth rates of $G$. demissa in South Carolina are high compared to other locations in the eastern U.S. Growth rates during the summer were similar to northern locations, but milder environmental conditions at this South Carolina site permit an extended growing season that results in higher overall growth rate in shell length
\end{abstract}

\section{INTRODUCTION}

Most studies of growth in bivalve molluscs use increases of shell length or weight over a given period of time as estimates of growth. Typically, growth in one parameter is assumed to be parallelled by an equivalent amount of growth in the remainder of the animal. Less frequently, growth in shell and soft tissue are independently determined. Hilbish (1986) illustrated that growth in shell length and soft tissue of bivalves need not be coincident in time, and demonstrated that in a population of Mytilus edulis, growth in shell preceded growth in soft tissue. Uncoupled rates of growth of shell and tissue may severely affect analyses of bivalve population dynamics, as well as estimates of population and community production. Several indices of condition used frequently for bivalves estimate condition as the proportion of a body component with respect to the total weight or volume of the animal (Walne \& Mann 1975, Lucas \& Beninger 1985). Therefore, these indices may be drastically affected by uncoupled rates of growth in shell and soft tissues, resulting in apparent changes of condition that do not

\footnotetext{
- Contribution No. 693 from the Belle W. Baruch Institute of Marine Biology and Coastal Research
}

necessarily correspond to real loses or gains of weight by the animals (Shafee 1980, Hiibish 1986, Bricelj et al. 1987).

Variation in a number of environmental parameters and endogenous cycles of the animals may result in non-coincident rates of shell and soft tissue growth. Conditions favorable to shell growth may occur at times other than those leading to increases of soft tissue. Materials from different sources are used for production of shell and soft tissue of bivalves. Changes in soft tissue weight are typically associated with seasonal variation in food availability (Bayne \& Newell 1983), the reproductive cycle (Bayne \& Worrall 1980), and patterns of energy storage and utilization (Gabbott 1976, Barber \& Blake 1981). On the other hand, shells have lower organic content than soft tissues (Jørgensen 1976, Price et al. 1976), and shell growth may have only partial dependence on metabolic carbon (Tanaka et al. 1986), since shell growth occurs largely through deposition of materials from the water (Wilbur \& Saleuddin 1983). Therefore, seasonal variation in food availability and levels of inorganic elements in the water may have different effects upon the rates of growth in shell and soft tissue.

In this study, separate determinations of shell and tissue growth of the ribbed mussel Geukensia 
demissa were obtained monthly from a mid-intertidal population in the North Inlet Estuary, South Carolina, USA. While previous studies have demonstrated that uncoupled growth of shell and soft tissue occur in bivalve populations, it is important to extend this studies to other species and latitudes. This would permit ascertaining the generality of this pattern of growth, and the potential for artifacts in studies of growth of bivalve molluscs. In addition, Hilbish (1986) used a limited size-range of animals, and the timing of shell and tissue growth may vary substantially among size classes (Peterson \& Fegley 1986). Therefore, the present study uses a wide range of size/age classes to examine patterns of growth in shell and soft tissue. We determine whether growth of these 2 parameters is coincident in time, and whether patterns of growth depend upon size or age class. Furthermore, this study provides age-specific growth trajectories for $C$. demissa, a dominant secondary producer on the eastern U.S. coast, and compares them with previous reports of shell growth at other locations.

\section{METHODS}

About 90 mussels ranging from 12 to $62 \mathrm{~mm}$ shell length were collected in January 1984 from a population that accurs on an intertidal oyster bed (Crassostrea virginica) in the North Inlet Estuary, South Carolina. This site is covered by water for an average of $8 \mathrm{~h} \mathrm{~d}^{-1}$. All specimens were scrubbed clean of epibionts, their shell length measured to the nearest $0.1 \mathrm{~mm}$ with Vernier calipers, and a number painted on the exterior of the shell. They were then placed in plastic flower pots (about $15 \mathrm{~cm}$ in diameter) which had been filled with empty oyster shells and sediment from the site, to resemble the natural substrate. About 5 mussels of various sizes were placed in each flower pot, a lower density than that of the natural population (Borrero 1985). The flower pots were covered with $1 \mathrm{~cm}$ meshsize plastic screen, to avoid predation by racoons, which occurred in preliminary experiments. The mussels were then returned to the site from were they had been collected, by burying the flower pots in the substrate up to their upper edges. Mussel growth was monitored about monthly between January and October 1984. On each date, the mussels were recovered, washed in running seawater, measured, and the numbers repainted if necessary. Mussels found dead were removed but not replaced. Daily growth for each individual was calculated by dividing the increase in shell length during each growth interval by the number of days elapsed. Mean daily growth was calculated both as an average for all mussels, and for each of 3 initial shell length classes to which mussels were assigned. ANOVA (Sokal \& Rohlf 1981) was used to test the effects of shell length (initial length) on mussel growth during the whole period, and during the summer and fall seasons, separately. Information on temporal variation in surface water temperature at the same general area was obtained from the Long Term Ecological Research Program of the University of South Carolina.

At each sampling date, approximately 25 individuals were collected from the natural mid-intertidal population. These were dissected, the soft tissues dried to a constant weight at $80^{\circ} \mathrm{C}$ and then weighed to the nearest $0.1 \mathrm{mg}$. Shell length of each individual was measured to the nearest $0.1 \mathrm{~mm}$ using Vernier calipers. A regression of dry soft tissue weight on shell length was generated for each monthly sample from the natural population. These regressions were used to calculate an estimate of the dry tissue weight for each individual of known length maintained in the flower pots. In this manner, growth in terms of tissue weight and shell length were monitored for each individual maintained in the flower pots.

This procedure assumes that shell growth in the flower pots is identical to shell growth in the natural population. Otherwise, measured shell growth would not be reflective of growth in the natural population. This assumption was tested by comparing shell growth curves based on age estimations of mussels maintained in the flower pots, with those from the natural population. Experimental mussels were placed in the flower pots in January 1984, and recovered in January 1986. A total of 29 individuals were recovered. An additional sample of 62 mussels was collected from the natural population at this time. The shell length of individuals from both samples was measured to the nearest $0.1 \mathrm{~mm}$. Age was determined for each individual by 2 separate methods. First, external growth checks on the shell of each mussel were counted and the relationship between shell length and number of growth checks was established. Annual growth checks could be recognized from other marks on the shells, following the suggestions given in Bertness (1980) and Brousseau (1984). Secondly, age estimations were obtained by sectioning the shells longitudinally through the umbo using a low speed saw, and counting the number of internal growth bands on the polished cut edge of the shells. A relationship between shell length and number of internal growth bands was obtained, and the growth trajectories obtained on the basis of external and internal growth bands were compared. In order to ascertain the accuracy of these age estimations, both techniques were calibrated against the measured length increments during the $2 \mathrm{yr}$ period of growth in the flower pots (January 1984 to January 1986 ). 


\section{RESULTS}

Daily specific growth rates $\left(\mathrm{mm} \mathrm{d}^{-1}\right)$ of mussels in the flower pots exhibited a seasonal pattern of variation, which resembled the temporal pattern of changes in surface water temperature (Fig. 1). The correlation coefficient between the 2 variables, however, was not significant $(\mathrm{r}=0.643, \mathrm{p} \approx 0.086)$. Little growth in shell length accurred between January and March, when lowest temperatures were recorded. Higher growth rates were observed between May and October, with the highest daily growth occurring in July (up to $0.143 \mathrm{~mm} \mathrm{~d}^{-1}$ ), when temperature was at its maximum. A significant effect of initial shell length on daily growth rate was observed (ANOVA, $p<0.005$ ), with small ( 10 to $25 \mathrm{~mm}$ ) and medium ( 26 to $40 \mathrm{~mm}$ ) mussels increasing in size at higher rates than large mussels (41 to $55 \mathrm{~mm}$ ) (Table 1). Small mussels increased in size more than 2-fold during the $10 \mathrm{mo}$ period, whereas large mussels increased by about a third of their initial size. Summer growth was about twice the growth in the fall for mussels of all sizes and there was a decline of the increase in shell length with increasing mussel size during all the time periods examined.

Analysis of covariance was used to determine the

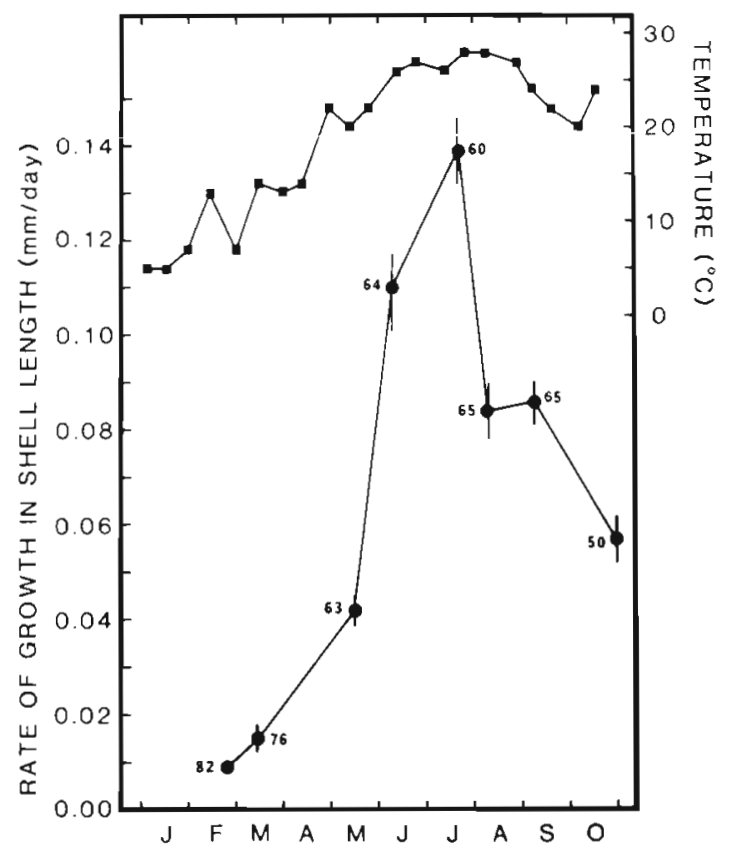

Fig. 1. Geukensia demissa. (•) Mean growth rate $\left(\mathrm{mm} \mathrm{d}^{-1}\right)$ of mussels in flower pots at a mid-intertidal site, between $11 \mathrm{Jan}$ and 31 Oct 1984. Sample size at each period is indicated next to each plotted symbol. Vertical bars represent one standard error of the mean. Also given ( $\boldsymbol{\sigma}$ ) is temporal variation in surface water temperature $\left({ }^{\circ} \mathrm{C}\right)$. Each symbol represents a single temperature measurement
Table 1. Geukensia demissa. Growth of mussels in flower pots at a mid-intertidal site, during summer (14 May to 9 Aug 1984) and fall (9 Aug to 31 Oct 1984), and during the total period of study (11 Jan to 31 Oct 1984)

\begin{tabular}{|lccrc|}
\hline $\begin{array}{l}\text { Initial } \\
\text { length } \\
\text { (mm) }\end{array}$ & $\begin{array}{c}\text { Range of } \\
\text { length in- } \\
\text { crease (mm) }\end{array}$ & $\begin{array}{c}\text { Mean length } \\
\text { increase } \\
(\mathrm{mm}) \pm \mathrm{SD}\end{array}$ & $\mathrm{n}$ & $\begin{array}{c}\text { Mean percent } \\
\text { length in- } \\
\text { crease }\end{array}$ \\
\hline Summer & & & & \\
$10-25$ & $7.7-18.2$ & $11.68 \pm 3.01$ & 12 & 66.74 \\
$26-40$ & $5.0-14.8$ & $10.88 \pm 2.71$ & 39 & 32.97 \\
$41-55$ & $4.0-10.7$ & $9.14 \pm 2.77$ & 9 & 19.04 \\
Fall & & & & \\
$10-25$ & $3.8-7.5$ & $5.47 \pm 1.27$ & 6 & 31.26 \\
$26-40$ & $1.2-11.0$ & $6.10 \pm 2.57$ & 35 & 18.48 \\
$41-55$ & $1.0-6.5$ & $3.22 \pm 2.12$ & 8 & 6.71 \\
Total period of study & & & \\
$10-25$ & $15.0-25.0$ & $18.27 \pm 3.58$ & 6 & 106.86 \\
$26-40$ & $10.5-25.7$ & $20.04 \pm 3.71$ & 34 & 60.73 \\
$41-55$ & $7.5-19.2$ & $13.24 \pm 3.24$ & 8 & 27.58 \\
\hline
\end{tabular}

mean tissue weight of a standard mussel of $58.1 \mathrm{~mm}$ in shell length, which is the grand mean in length of all mussels collected from the natural population. Significant temporal variation in adjusted dry soft tissue weight was observed in the monthly samples collected from the natural population during 1984 (Fig. 2). There

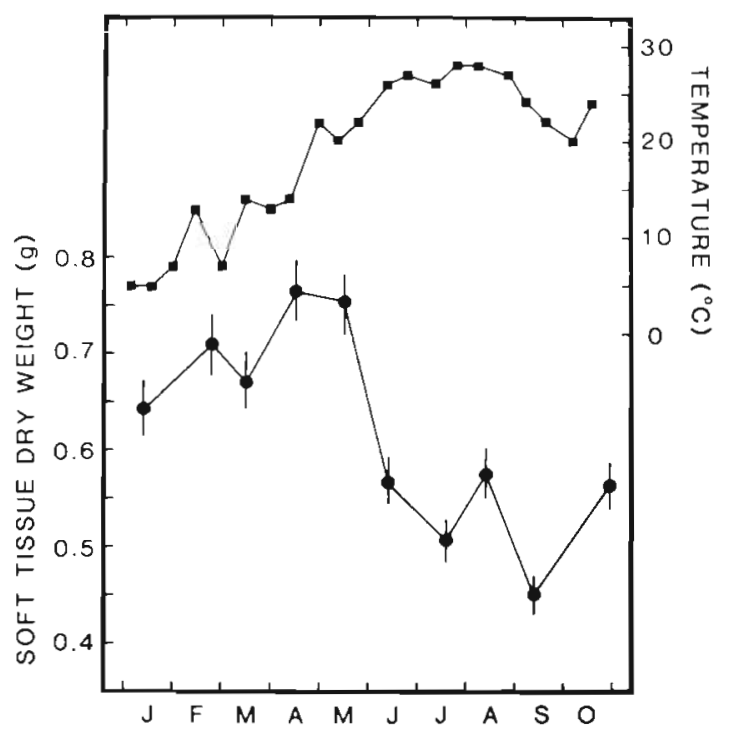

Fig. 2. Geukensia demissa. (•) Seasonal variation in covariance-adjusted total soft tissue dry weight of mussels from a mid-intertidal natural population in 1984. Plotted symbols represent the mean of about 25 individuals, adjusted to a standard individual of $58.1 \mathrm{~mm}$ length. Vertical bars are 1 standard error of the mean. Also given ( $\square$ ) is temporal variation in surface water temperature. Each symbol represents a single temperature measurement 
was no significant variation in the slopes of the regressions of tissue weight on shell length $(p>0.05)$. Adjusted soft tissue weight exhibited a general increase between January and April, and then a steep decline from May to July, with the mussels losing about $35 \%$ of their adjusted weight during this period. Between July and August a slight increase in adjusted

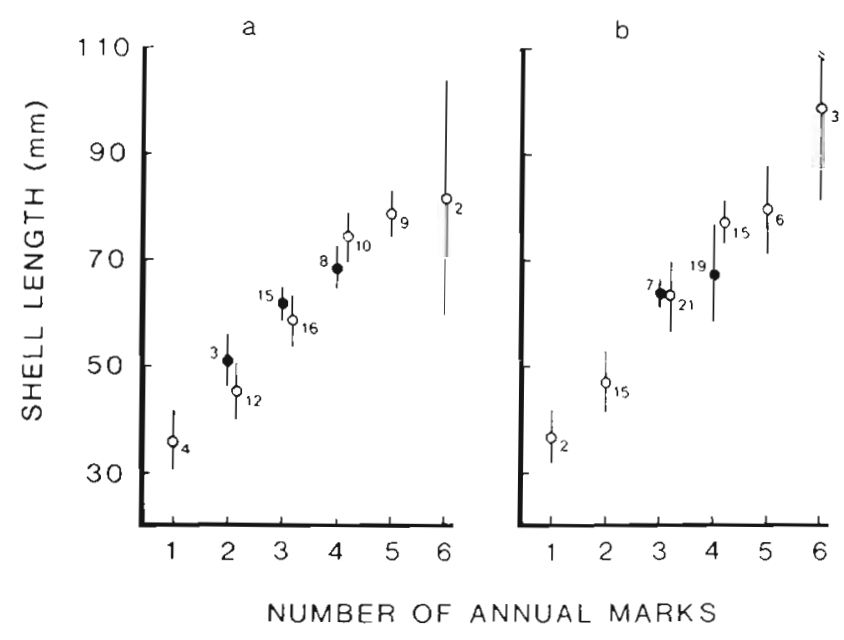

Fig. 3. Geukensia demissa. Age-length growth trajectories of mussels from the natural population $(0)$ and flower pots (•), at a mid-intertidal site in January 1986, based on (a) external shell marks, and (b) internal shell marks. Each symbol represents the mean of the number of mussels indicated next to it.

Vertical bars are $95 \%$ confidence limits about the mean

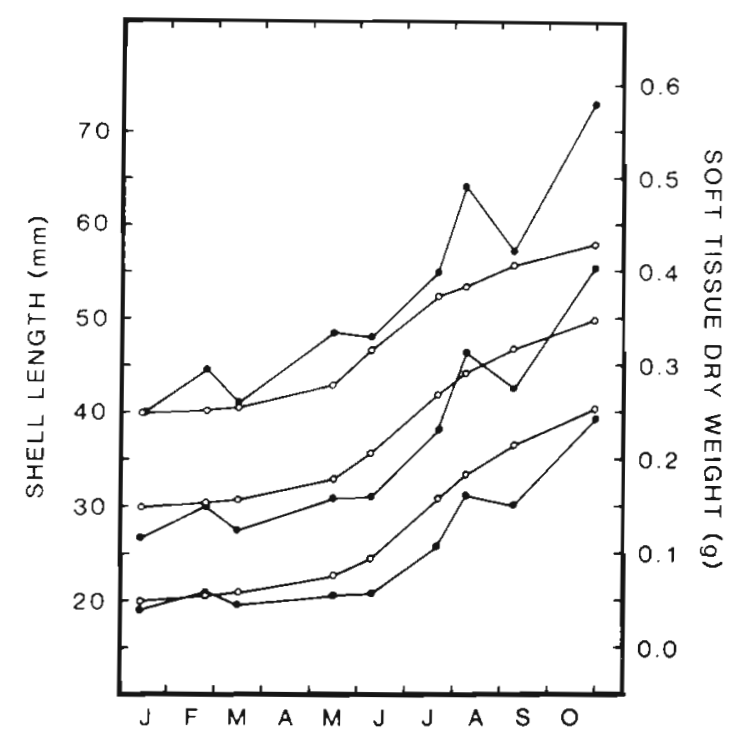

Fig. 4. Geukensia demissa. Reconstructed growth trajectories of shell (o) and soft tissue ( $\bullet$ ) of standard mussels of 20,40 , and $60 \mathrm{~mm}$ in initial shell length. See text for details on methods used soft weight was observed, after which another decline took place between August and September. Adjusted tissue weight increased between September and October. The increase in weight between January and April was coincident with increasing water temperature, but maxima of tissue weight, and subsequent decline, occurred much before the maxima of water temperature in the area (Fig. 2).

There was good agreement between the shell growth histories constructed on the basis of external and internal growth marks (Fig. 3). The variance about the mean shell length for each age increment was slightly smaller with the estimations based on external marks, suggesting higher accuracy of this method. After $2 \mathrm{yr}$ of growth, 15 mussels were recovered from the flower pots with their ariginal painted numbers in January 1986; 2 external shell marks were observed in some individuals, whereas 1 mark plus some additional growth was observed in others. This suggests that the deposition of external growth marks is about annual, their appearance occurring during the winter in this population. In South Carolina, this probably occurs between December and February. Mussels from the flower pots exhibited the same shell length per unit age as mussels from the natural population, irrespective of whether internal or external shell marks were used to estimate age (Fig. 3). These results indicate that residence for $2 \mathrm{yr}$ in the flower pots had no significant effect on rates of shell growth. This validates our assumption that the pattern of shell growth in the flower pots reflects shell growth in the natural population.

Shell and soft tissue growth were estimated at each monthly sample interval for a total of 41 mussels from the flower pots. Individuals that did not survive the entire monitoring period were not used. For each individual, size at each time interval was regressed against its size in January 1984. Using this regression, the estimated growth history for individuals that were initially 20,30 , and $40 \mathrm{~mm}$ in shell length were constructed (Fig. 4). The average initial size was $31.8 \mathrm{~mm}$, so these size classes take in the majority of individuals that were included in the study. Shell and soft tissue growth were not coincident in time. Percentage change in weight and shell length were calculated for the $30 \mathrm{~mm}$ size class. The correlation between relative rates of growth in shell and soft tissue was not significant $(r=0.481, d f=6)$. Between August and September mussels lost weight due to spawning (Borrero 1987), and therefore the loss of body mass during this period is not reflective of growth. If this interval is excluded from the analysis, the correlation between percent change in shell length and soft tissue remains non-significant ( $r=0.451$, $\mathrm{df}=5$ ).

The patterns of growth in shell and soft tissue were very similar among size classes (Fig. 4), Rates of growth 
of both shell and soft tissue are greater for the initially smaller size class, which is to be expected from standard allometric relations of invertebrate growth. However, there appear to be no significant differences among size classes in the timing of either shell or of soft tissue growth

\section{DISCUSSION}

Growth in shell and soft tissue were not coincident in this population of Geukensia demissa. Relative rates of soft tissue growth were highly variable between January and May. After May, rates of soft tissue growth were consistently high until the end of the study in October. Spawning occurred between August and September, which obscured accurate estimates of soft tissue growth during this interval. By contrast, relative shell growth increased steadily through the year to a maximum between June and July. After this period, relative rates of shell growth declined to lower levels. There was no significant correlation between relative rates of shell and soft tissue growth. Between May and June, mussels lost weight while shell growth continued at a high rate. In the fall, tissue growth rates were at their maximum, while the rate of shell growth had declined. Therefore, growth in shell and soft tissue were not temporally coincident in this population. Because of the erratic changes in relative soft tissue growth before May, it is difficult to determine much seasonality in tissue growth rates. It appcars that a large increase in both shell and tissue growth was initiated in June, but that shell growth rates declined while tissue growth remained high. These results are similar to those of Hilbish (1986) in that a major period of tissue growth occurs after the period of high rates of shell growth. Data from Jordan \& Valiela (1982) also indicate that shell growth declined in the fall while soft tissue continued to increase at a high rate in a population of $G$. demissa from Massachusetts, USA.

No significant differences were detected among size classes in the timing of growth in shell or soft tissue. In contrast, temporal displacement among size classes in the rates of growth in shell and/or soft tissue have been reported for other populations of bivalves. In New Hampshire, USA, the maximum mean growth rates in shell length of small Geukensia demissa occurred 1 mo earlier than the mean maximum for large mussels (Hardwick-Witman 1985). Similarly, Peterson \& Fegley (1986) found significant difference in the temporal variation of growth in shell between juvenile and adult Mercenaria mercenaria from North Carolina. In this case, shell growth of juvenile clams was disproportionally high compared to adult clams during part of the study. In the present study from South Carolina, we did not observe this type of size/age related variation in growth rates. The patterns of growth in shell and soft tissue were very similar among size classes.

Other studies have demonstrated that shell and soft tissue growth may be temporally uncoupled. Hilbish (1986) found no significant correlation between relative rates of shell and soft tissue of Mytilus edulis from Long Island Sound, New York, USA. Ceccherelli \& Barboni (1983) studied the growth of populations of Mytilus galloprovincialis of known age and similar age/size distribution, cultured at 2 sites. Growth in shell length was not significantly different among the sites, whereas soft tissue growth exhibited major differences, both in timing and in magnitude. Similarly, Frechette \& Bourget (1985) observed that shore level and height above the bottom were correlated with large differences in increases of soft tissue weight of experimental groups of $M$. edulis, whereas neither factor had a significant effect on changes in shell length. Kautsky (1982) likewise observed uncoupled growth between shell and soft tissue in $M$. edulis. Therefore, it is clear that a lack of coincidence in growth of shell and soft tissue is a frequent condition in bivalve populations. The factors that control growth of these parameters, particularly shell growth, are poorly known.

Hilbish (1986) demonstrated that uncoupled rates of shell and tissue growth seriously affect 'adjustedweight cycles', where soft tissue weights are statistically adjusted to a standard shell length using analysis of covariance. This potential for artifact is evident in the present study. In this case, there is a large deciine in adjusted weight between May and June, which continues through July. The reconstructed growth curve demonstrates that there was only a minor change in weight between May and June, while during June and July there was a high rate of tissue growth. This discrepancy is generated by the relatively high rate of shell growth during a period of low growth in tissue, and is virtually identical to the observation of Hilbish (1986) for Mytilus edulis. Bricelj et al. (1987) pointed out a similar situation for the scallop Argopecten irradians, for which apparent declines of soft tissue weight (adjusted to shell height by covariance) may not have occurred, or may have been much less pronounced. Shafee (1980) indicated also that the increase in size of the shell in a given time may not actually represent the growth of the body tissue in bivalves.

Non-coincident rates of soft tissue and shell growth have major practical implications in studies of bivalve populations. Precise knowledge of the temporal relationship of shell and tissue production is of great importance to identify optimal harvesting times of cultured bivalves (Loo \& Rosenberg 1983, Lucas \& Beninger 1985), and culture conditions may result in major temporal and quantitative differences in the 
patterns of productivity (MacDonald 1986). The physiological costs associated with growth in shell and tissue, and the proportion of energy allocated to these and other body components, can exhibit a large degree of variation within and among bivalve populations (Thompson 1979, MacDonald \& Thompson 1986, Peterson \& Fegley 1986). Nielsen (1985) observed a significant linear correlation between increase in ash-free dry weight and increase in shell length of Mytilus edulis within short time periods, and concluded that the 2 variables are closely coupled and thus increase in ashfree dry weight can be calculated from increase in shell length. However, the results presented by Frechette \& Bourget (1985) using the same species and similar time periods indicate that growth in shell and soft tissue did not parallel each other. Therefore, the technique of Nielsen (1985) cannot be applied in all cases, previous to evaluating it in local environmental circumstances and physiological condition of the animals. Unlike small bivalves, old bivalves grow little in shell length, but undergo tremendous annual changes in soft tissue that are partially related to their reproductive cycle. Therefore, size and age structure, and the relationship between shell and tissue growth for animals of different ages, must be considered in studies of population and community production (Kautsky 1981, Navarro \& Winter 1982, Peterson \& Fegley 1986). Using weightlength relations determined at one time of the year or for a limited size range may result in inaccurate estimations of production.

Results from this study indicate that external growth bands in the shells of mussels from this population are formed annually, during the winter. Since spawning of populations of Geukensia demissa in the North Inlet Estuary occurs yearly between August and September (Borrero 1987), and spat settlement occurs between September and October (Borrero 1985), some growth in shell would occur previous to the first winter of life of the juvenile mussels. We do not have data on whether an external shell mark is formed during the first winter of life. Therefore, it is possible that we are underestimating the age of mussels by about $1 \mathrm{yr}$, which is a limitation of the aging techniques used (Lutz \& Castagna 1980, Brousseau 1984). This may partially explain why the rates of growth in shell length obtained from the age-length curves appear slightly slower than those obtained from the reconstructed shell growth trajectories of mussels from the flower pots. These rates, however, are generally within close proximity of each other.

Brousseau (1984) reviewed data on growth of Geukensia demissa throughout the East Coast of the United States and concluded that there is no clearcut relation between latitude and growth rate in shell length of this species. Our data support this conclusion; annual growth rates observed in this study were greater than those reported for more northern sites (Bertness 1980, Brousseau 1984, Bertness \& Grosholz 1985), while the lowest rates yet reported occurred at a nearby location in Georgia (Kuenzler 1961). Size-specific growth rates are similar among localities in the summer, but the growing season is longer in South Carolina, which results in enhanced annual growth. It is probable that locality-specific circumstances influence the growth rate of $G$. demissa (Stiven \& Kuenzler 1979) more than do more general environmental changes associated with latitude. However, the shape of the age-length curves suggest that mussels may considerably reduce the rate of shell growth at an earlier age in populations studied from South Carolina and Georgia, than at other locations for which data are available. The inflection of the age-length curve occurs between 5 and $7 \mathrm{yr}$ of age in South Carolina and Georgia, while in Connecticut and Virginia this inflection occurs at 9 to 12 yr of age (Lutz \& Castagna 1980 , Brousseau 1984). Therefore, there may be a latitudinal trend in the relationship between shell growth and age among populations of $G$. demissa.

Acknowledgements. We thank Mrs Kerry Zimmerman for technical assistance on shell sectioning. Dr D. Edwards and Mr W. K. Michener provided assistance with computer programming. FJB thanks Dr F. J. Vernberg for his support and criticism. Funding was provided by the Department of Biology, the Belle W. Baruch Institute for Marine Biology and Coastal Research, Research and Productive Scholarship, the University of South Carolina, and the Aquaculture Fellowship from the South Carolina Wildlife and Marine Resources Department, Marine Resources Division.

\section{LITERATURE CITED}

Barber, B. J., Blake, N. J. (1981). Energy storage and utilization in relation to gametogenesis in Argopecten irradians concentricus. J. exp. mar. Biol. Ecol. 52: 121-134

Bayne, B. L., Newell, R. C. (1983). Physiological energetics of marine molluscs. In: Saleuddin, A. S. M., Wilbur, K. M. (eds.) The Mollusca, Vol. 4, Physiology, Part 1. Academic Press, New York, p. 407-515

Bayne, B. L., Worrall, C. M. (1980). Growth and production of mussels Mytilus edulis from two populations. Mar. Ecol. Prog. Ser. 3: $317-328$

Bertness, M. D. (1980). Growth and mortality in the ribbed mussel Geukensia demissa. Veliger 23: 62-69

Bertness, M. D., Grosholz, E. (1985). Population dynamics of the ribbed mussel, Geukensia demissa: the costs and benefits of an aggregated distribution. Oecologia (Berl.) 67: $192-204$

Borrero, F. J. (1985). The ecology of Geukensia demissa in the North Inlet Estuary, South Carolina: shell shape, reproductive and soft tissue content cycles, population structure, and growth. M.Sc. thesis, Univ. of South Carolina

Borrero, F. J. (1987). Tidal height and gametogenesis: reproductive variation among populations of Geukensia demissa. Biol. Bull. mar biol. Lab., Woods Hole 173 160-168 
Bricelj, V. M., Epp, J., Malouf, R. E. (1987). Intraspecific variation in reproductive and somatic growth cycles of bay scallops, Argopecten irradians. Mar. Ecol. Prog. Ser 36: 123-137

Brousseau, D. J. (1984). Age and growth rate determinations for the Atlantic ribbed mussel, Geukensia demissa Dillwyn (Bivalvia: Mytilidae). Veliger 7 (3): 233-241

Ceccherelli, V U., Barboni, A. (1983). Growth, survival and yield of Mytilus galloprovincialis Lamk. on fixed suspended culture in a bay of the Po River delta. Aquaculture 34: 101-114

Frechette, M., Bourget, E. (1985). Food-limited growth of Mytilus edulis $\mathrm{L}$. in relation to the benthic boundary layer. Can. J. Fish. Aquat. Sci. 42 (6): 1166-1170

Gabbott, P. A. (1976). Energy metabolism. In: Bayne, B. L. (ed.) Marine mussels: their ecology and physiology. Cambridge Univ. Press, Cambridge, p. 293-355

Hardwick-Witman, M. N. (1985). Biological consequences of ice rafting in a New England salt marsh community. J. exp. mar Biol. Ecol. 87: 283-298

Hilbish, T. J. (1986). Growth trajectories of shell and soft tissue in bivalves: seasonal variation in Mytilus edulis L. J. exp. mar. Biol. Ecol. 96: 103-113

Jordan, T. E., Valiela, I. (1982). A nitrogen budget of the ribbed mussel, Geukensia demissa, and its significance in nitrogen flow in a New England salt marsh. Limnol. Oceanogr. 27 (1): 75-90

Jorgensen, C. B. (1976). Growth efficiencies and factors controlling size in some mytilid bivalves, especially Mytilus edulis L.: review and interpretation. Ophelia $15(2)$ : $175-192$

Kautsky, N. (1981). On the trophic role of the mussel (Mytilus edulis L.) in a Baltic coastal ecosystem and the fate of the organic matter produced by the mussels. Kieler Meeresforsch. (Sonderh.) 5: 454-461

Kautsky, N. (1982). Growth and size structure in a Baltic Mytilus edulis population. Mar. Biol. 68: 117-133

Kuenzler, E. J. (1961). Structure and energy flow of a mussel population in a Georgia salt marsh. Limnol. Oceanogr. 6: 191-204

Loo, L. O., Rosenberg, R. (1983). Mytilus edulis culture growth and production in western Sweden. Aquaculture 35: $137-150$

Lucas, A., Beninger, P. G. (1985). The use of physiological condition indices in marine bivalve aquaculture. Aquaculture 44: 187-200

Lutz, R., Castagna, M. (1980). Age composition and growth rate of a mussel (Geukensia demissa) population in a Virginia salt marsh. J. mollusc. Stud. 46: 106-115
MacDonald, B. A. (1986). Production and resource partitioning in the giant scallop Placopecten magellanicus on the bottom and in suspended culture. Mar. Ecol. Prog. Ser. 34 : $79-86$

MacDonald, B. A., Thompson, R. J. (1986). Production, dynamics and energy partitioning in two populations of the giant scallop, Placopecten magellanicus (Gmelin). J. exp. mar Biol. Ecol. 101: 285-299

Navarro, J. M., Winter, J. E. (1982). Ingestion rate, assimilation efficiency and energy balance in Mytilus chilensis in relation to body size and different algal concentrations. Mar. Biol. 67: 255-266

Nielsen, M. V. (1985). Increase in shell length as a measure of production and ingestion of Mytilus edulis L. J. exp. mar. Biol. Ecol. 88: 101-108

Peterson, C. H., Fegley, S. R. (1986). Seasonal allocation of resources to growth of shell, soma, and gonads in Mercenaria mercenaria. Biol. Bull. mar. biol. Lab., Woods Hole 171. $597-610$

Price, T. J., Thayer, G. W., La Croix, M. W., Montgomery, G. P. (1976). The organic content of shells and soft tissues of selected estuarine gastropods and pelecypods. Proc. natl Shellfish. Ass. 65: 26-31

Shafee, M. S. (1980). Application of some growth models to the black scallop, Chlamys varia (L.) from Lanveoc, Bay of Brest. J. exp. mar. Biol. Ecol. 43: 237-250

Sokal, R. R., Rohlf, F. J. (1981). Biometry. Freeman, New York

Stiven, A. E., Kuenzler, E. J. (1979). The response of two salt marsh molluscs, Littorina irrorata and Geukensia demissa, to field manipulations of density and Spartina litter. Ecol. Monogr 49: 151-171

Tanaka, N., Monaghan, M., Rye, D. M. (1986). Contribution of metabolic carbon to mollusc and barnacle shell carbonate. Nature, Lond. 320: 520-523

Thompson, R. J. (1979). Fecundity and reproductive effort in the blue mussel (Mytilus edulis), the sea urchin (Strongylocentrotus droebachiensis), and the snow crab (Chionoecetes opilio) from populations in Nova Scotia and Newfoundland. J. Fish. Res. Bd Can. 36: 955-964

Walne, P. R., Mann, R. (1975). Growth and biochemical composition in Ostrea edulis and Crassostrea gigas. In: Barnes, H. (ed.) Proceedings 9th European Marine Biology Symposium. Aberdeen Univ. Press, Aberdeen, p. 587-607

Wilbur, K. M., Saleuddin, A. S. M. (1983). Shell formation. In: Saleuddin, A. S. M., Wilbur, K. M. (eds.) The Mollusca, Vol. 4, Physiology, Part 1 Academic Press, New York, p. $235-287$

This article was presented by Professor F. J. Vernberg; it was accepted for printing on October 23, 1987 